\title{
Real wages, inflation and labour productivity in Australia
}

\author{
Saten Kumar, Don J. Webber and Geoff Perry \\ Department of Business Economics, Auckland University of Technology, New Zealand
}

\begin{abstract}
This paper presents an analysis of real wages, inflation and labour productivity interrelationships using cointegration, Granger-causality and, most importantly, structural change tests. Applications of tests to Australian data over the 1965-2007 period corroborate the presence of a structural break in 1985 and show that a 1 percent increase in manufacturing sector real wages led to an increase in manufacturing sector productivity of between 0.5 and 0.8 percent. Comparable estimates for the effect of inflation on manufacturing sector productivity have limited statistical significance. Granger causality test results suggest that real wages and inflation both Granger-cause productivity in the long run.
\end{abstract}

Keywords: Labour productivity; Real wages; Inflation; Cointegration; Granger causality

JEL: C50; E23

Acknowledgements: The authors are grateful to Professors B. Bhaskara Rao, Dimitris Christopoulos, Erinc Yeldan, Jack Strauss, Peter Howells and Toni Mora for comments on earlier drafts. All errors are the authors' responsibility.

Corresponding author: Don J. Webber, Department of Economics, Auckland University of Technology, Auckland, New Zealand. Email: Don.Webber@aut.ac.nz 


\section{Introduction}

There are a number of reasons why associations may exist between real wages, inflation and productivity, as hypothesised by Bardsen et al. (2007, p. 145). It is almost standard in the theoretical literature to envisage that inflation and productivity growth are negatively related as workers purchasing power affects motivation and effort, but also because inflation affects firms' investment plans, influences capital depreciation rates and induces changes in the choices of production techniques.

Some posit that real wages and productivity are positively related (Wakeford, 2004). Two main arguments are relevant here. First, higher real wages increase the opportunity cost of job loss, which can stimulate greater work effort to avoid redundancy (an efficiency-wage type hypothesis). Second, an increase in real wages will result in an increase in the unit cost of labour and cause firms to substitute capital for labour, which will be reflected in an increase in the marginal productivity of labour. Gordon (1987) highlights that substitution from labour to capital in response to inexorable increases in real wages has been at the heart of the economic growth process for centuries. Of course, inflation and real wages are also related and Hendry (2001) shows succinctly that inflation responds to excess demands in many parts of an economy including labour costs within the labour market.

Recognition and strong evidence of real wages, inflation and productivity interrelationships can help shape policy formation for productivity enhancement, inflation control or consumption stimulation. Although some studies have focused on this set of interrelationships using a range of cointegration techniques, none have controlled for structural breaks and, therefore, may provide misleading results. This is the first paper to present an analysis of the interrelationships between inflation, real wages and productivity using a comprehensive set of cointegration, Granger causality and structural change tests. Applications of these tests to Australian data over the period 1965-2007 reveal a number of important insights.

In the 1950s and 1960s the Australian government actively followed import substitution policies that failed to stimulate strong manufacturing sector growth. Fortuitously mining initiatives, often associated with foreign direct investments, enthused the economy's continued expansion. The 1980s saw the arrival of the much-heralded Hawke Labour government (1983-1991) which cut tariffs, stopped the construction of the infamous Franklin Dam, floated the Australian dollar (1983), reformed the tax system, amalgamated the Australian state-specific stock exchanges into one Australian Stock Exchange (1987), and fought through the mid-1980s terms of trade problems and the late 1980s recession with high interest rates. The Labour government continued to privatise important companies (including Qantas in 1993) under the leadership of Paul Keating (1991-1996) and steered Australia through a period of relatively slow economic growth only to be superseded by John Howard's government (1996-2007) which introduced a goods and service tax (1998), spending cuts to eliminate the budget deficit, and the Workplace Relations Act (1997) to reshape the Australian labour market. Such major changes in the Australian economy must be associated with structural changes in the domestic economy (McKissack et al., 2008) which should be included in estimations of cointegration; the absence of controls for structural change could result in the incorrect acceptance or rejection of a cointegrating relationship.

The objective of this article is to examine empirically the effect of real wages and inflation on productivity for the Australian economy over the period 1965 to 2007 using a comprehensive set of empirical tests. This paper reports the results of cointegration tests and estimates of cointegrating vector parameters undertaken through application of Johansen's $(1988,1991)$ Vector Error Correction Method (VECM) as well as tests for structural breaks 
in the cointegrating relationships that are obtained through the application of Gregory and Hansen's (1996a, 1996b) technique (GH). Application of VECM based Granger causality methods are undertaken to test for causality between the variables. Furthermore, long run estimates are compared with other time series techniques (including General to Specific (GETS), Engle and Granger (EG), Phillip Hansen's Fully Modified Ordinary Least Squares (FMOLS) and Autoregressive Distributed Lag (ARDL)) to identify the consistency and stability of results across statistical methods. For the first time in the literature, we provide long run estimates for the effect of real wages and inflation on productivity in Australia that include tests for structural change.

The remainder of this paper has the following structure. Section 2 is a brief overview of the empirical literature. Section 3 provides details of data and methodology. Section 4 is a discussion of the empirical results. Concluding remarks are collated in Section 5.

\section{Brief overview of the empirical literature}

The relationships between inflation, real wages and productivity growth has received much attention in the empirical literature. ${ }^{1}$ This literature is characterised by the application of a variety of different empirical tests on data sets corresponding to a variety of economies.

\section{Inflation and productivity}

Many conceive that inflation and productivity growth are negatively related (Jaret and Selody, 1982; Clark, 1982; Hondroyiannis and Papapetrou, 1997). For instance, inflation reduces the incentive to work, distorts the informational content of relative price levels (leading to inefficient investment plans), and shrinks tax reductions for depreciation (resulting in an increase in the rental price of capital); all of these will indirectly constrain productivity growth (Christopoulos and Tsionas, 2005). Narayan and Smyth (2009) surmise further possible mechanisms through which inflation can adversely affect labour productivity, including the movement towards an inefficient mix of factor inputs, an increase in buffer stocks and a reduction in R\&D expenditures.

Four important empirical studies suggest there is a negative relationship between inflation and productivity. Bitros and Panas (2001) examined the effect of inflation on total factor productivity across Greek manufacturing industries between 1964 and 1980. They found that the acceleration of inflation from the period 1964-1972 to 1973-1980 led to a significant slowdown in total factor productivity in 16 out of 20 manufacturing industries. Tsionas (2003a) also found a negative relationship between inflation and productivity for fifteen European countries over the period 1960-1997. While their application of Bayesian techniques revealed no cointegration, their application of the VECM technique did suggest a negative relationship between inflation and productivity for most countries. Further, their causality test results imply that there is bi-directional causality between inflation and productivity for five countries while one-way causality exists for two countries.

Christopoulos and Tsionas's (2005) application of panel cointegration techniques to

\footnotetext{
In addition to those discussed elsewhere in this paper the list includes: Geary (1976), Denny and May (1977), Gordon (1984, 1988), Buck and Fitzroy (1988), Crafts (1992), De Gregorio (1992), Sbordone and Kuttner (1994), Smyth (1995), Cameron et al. (1996), Feijo (1997), Palokangas (1997), Hondroyiannis and Papapetrou (1998), Freeman and Yerger (2000), Blanchard and Katz (1999), Fountas et al. (1999), Ghali (1999), Tsionas (2003b), Dritsakis (2004), L'horty and Rault (2004), Hsu (2005), Mahadevan and AsafuAdjaye (2006) and Bildirici and Alp (2008).
} 
European data over the period 1961-1999 also imply a long run negative relationship between inflation and productivity growth in seven of the fifteen countries.

Mahadevan and Asafu-Adjaye's (2005) application of Granger causality tests to domestic inflation and mineral product price data for the Australian mining sector provides results that imply a negative unidirectional causality ran from prices to mining productivity growth between 1968 and 1998. However, Freeman and Yerger (1998), who utilized Engle and Granger (1987) and Hsiao's (1981, 1982) Granger causality tests to examine the link between inflation and productivity using data from 1955-1994 for 12 OECD countries, argue that the correlation between inflation and productivity is spurious due to the cyclical movements between them.

One main reason for a lack of consensus behind the inflation-productivity relationship may be the omission of an explicit consideration of real wages. For instance, using US data Mehra (1991) examined the relationship between inflation and productivity adjusted wages and found that in the long run inflation had a positive effect on per-unit labour costs. Mehra's $(1993,2000)$ own re-examinations assert that in the long run there is a bi-directional relationship between these variables.

\section{Real wages and productivity}

A positive relationship between real wages and productivity is often hypothesised because higher real wages increase the opportunity cost of job loss and stimulate greater work effort to avoid redundancy. This positive relationship is also hypothesised because higher real wages put upward pressure on labour costs and cause firms to substitute capital for labour, thereby increasing the marginal productivity of labour (Wakeford, 2004). The relationship between real wage and productivity is also based on the concept that greater capital stocks increase the demand for labour, thereby increasing the real wage, and stimulating productivity. Similarly it is possible that domestic pressures on real wages stimulate movements towards the adoption of capital thereby increasing measures of productivity.

Erenburg (1998) examined the long run relationship between real wages and productivity in the US from 1948-1990 and identified a long run, counter-cyclical relationship between real wages and productivity once the empirical stance had controlled for capital stocks. Their main findings imply that if the public capital stock had remained constant then both real wages and productivity would have increased. However, using panel cointegration techniques Mora et al. (2005) examined the convergence in wages and productivity for eleven European countries for the period 1981-2001 and found reductions in the dispersion of nominal wages and unit labour costs, but did not find similar dispersion reductions in productivity or real wages.

\section{Inflation, real wages and productivity}

It is not unusual to amalgamate the above relationships for the purpose of empirical testing. For instance, Narayan and Smyth (2009) used panel cointegration techniques to examine the relationships between inflation, real wages and productivity growth for the G7 countries over the period 1960-2004. They found a positive statistically significant relationship between real wages and productivity growth but no statistically significant relationship between inflation and productivity growth.

Other empirical studies have taken a within country focus. For instance, Strauss and Wohar (2004) examined the long run relationship between inflation, real wages and productivity for a panel of 459 US manufacturing industries between 1956-1996 and found 
that in the long run inflation Granger-causes productivity, while bi-directional Granger causality runs between real wages and productivity. Hall (1986) and Alexander (1993) found empirical evidence that inflation, real wages and productivity have a cointegrating relationship in the UK, with an implication that higher wage rates stimulate labour productivity via the efficiency wage argument. Finally Gunay et al. (2005) examined the relationship between inflation, real wages and profit margins over twenty-nine Turkish manufacturing sub-sectors over the period 1980-1996 and found that profit margins (markups) are positively and significantly affected by real wage costs and price inflation; similar conclusions were obtained for Turkey by Blanchard (1985) and Metin-Ozcan et al. (2002).

\section{Empirical concerns}

In relation to these and other earlier empirical studies the following three points must be stressed. First, most studies used standard time series or panel data techniques but failed to consider structural changes in the cointegrating vector. Since the early 1980 s many countries, including Australia, have undergone significant structural changes and, therefore, it has become necessary to test for structural breaks in cointegrating relationships. Second, some of the previous empirical studies have been conducted using cointegration analysis with small sample sizes. This may significantly distort the power of the standard tests and lead to misguided conclusions. Third, most empirical studies have ignored the role of real wages on the relationship between inflation and productivity. Given these empirical concerns the remainder of this paper seeks to empirically investigate the effect of inflation and real wages on productivity for the Australian economy over a 43 year period using a comprehensive set of empirical tests which include the explicit inclusion of a structural change test.

\section{Data and methodology}

This study employs annual data on the rate of inflation (proxied by the growth of the consumer price index), real wages (proxied by hourly compensation in the manufacturing sector) and productivity (proxied by output per hour in the manufacturing sector) for Australia over the period 1965 to $2007 .^{2}$ Data were obtained from the International Financial Statistics (2008). Following Hondroyiannis and Papapetrou (1997) and Strauss and Wohar (2004) we specify the production function as follows:

$$
\ln Y_{t}=\alpha+\beta_{1} \ln W_{t}+\beta_{2} \ln \pi_{t}+\varepsilon_{t}
$$

where $\ln Y$ is the natural $\log$ of productivity, $\ln W$ is the natural $\log$ of real wages, $\ln \pi$ is the natural $\log$ of inflation and $\varepsilon$ is an iid error term. The estimates of $\beta_{1}$ and $\beta_{2}$ signify wage and inflation elasticities with respect to productivity.

\section{Structural breaks and cointegration}

Over the latter part of the $20^{\text {th }}$ Century many countries, including Australia, underwent significant economic structural change and thus it has become necessary to test for structural breaks in cointegrating relationships. Accordingly we employ Gregory and Hansen (1996a,

2 Our productivity measure is output per hour per worker which is calculated as total industrial output (in monetary terms) divided by the total industrial employment. Nominal wages are deflated by the consumer price index to provide a measure of workers' real purchasing power. 
1996b) tests (henceforth GH) to search for break dates in the cointegrating vector, where the null hypothesis is that there is no cointegration with structural breaks against the alternative of cointegration with structural breaks, and where the single break date is endogenously determined. The four models proposed by $\mathrm{GH}$ are based on alternative assumptions about structural breaks based on (1) level shift; (2) level shift with trend; (3) regime shift where both the intercept and the slope coefficients change and (4) regime shift where intercept, trend and slope coefficients change. ${ }^{3}$

We examine the long run relationship between inflation, real wages and productivity with the VECM technique developed by Johansen $(1988,1991)$, which is a system based method that uses maximum likelihood to determine the presence of cointegrating vectors and is based on the following vector autoregressive (VAR) model:

$$
\Delta y_{t}=C+\sum_{i=1}^{k} \theta_{i} \Delta y_{t-1}+\Pi y_{t-1}+\varepsilon_{1 t}
$$

where $y_{t}$ is a vector of $I(1)$, nonstationary in level form variables and $C$ is a constant. The information on the coefficient matrix between the levels of the stock price series is decomposed as $\Pi=\gamma \delta^{\prime}$, where the relevant elements of the matrix are the adjustment coefficients and the $\delta$ matrix contains the cointegrating vectors. The pre-testing of variables for unit root properties is vital and all variables are assumed to be endogenous; exogeneity is confirmed with application of formal tests.

The first step is to perform the lag specification tests where the number of lags in the VAR model is determined by the Schwarz Bayesian Criterion (SBC) and the Akaike Information Criterion (AIC). The second step is to test for cointegration. Johansen and Juselius (1990) propose the trace and maximal eigenvalue test statistics to determine the number of cointegrating vectors. These tests allow for (un)restricted intercept and restricted/no trend options for the VAR. Finally, the third step is to estimate the cointegrating vector.

The short run dynamic adjustment equations are estimated following endogeneity and identification tests. The exogeneity test concerns Granger non-causality with the null being that the coefficients of the lagged dependent variables are insignificant in the equations of the independent variables. Identification is tested by regressing the first differences of each variable on the one period lagged residuals normalized on respective variables, and identification is confirmed if the respective error correction terms are significant with negative signs in their own equations.

\section{Granger Causality}

The existence of cointegration implies Granger causality but it does not indicate the direction of causality. In order to test for Granger causality between inflation, real wages and productivity, we model the three variables within a VECM framework and evidence henceforth of a cointegrating relationship among variables implies that the Granger causality test model should be augmented with a one period lagged error correction term. According to Engle and Granger (1987) the vector autoregressive estimation in first differences will be ambiguous if the series are integrated of order one, and so we arrive at the following for Granger causality:

3 For more details on these tests, see Rao and $\operatorname{Kumar}(2007,2009)$ and $\operatorname{Kumar}(2009)$. 


$$
\begin{aligned}
& \Delta \ln Y_{t}=v+\sum_{i=1}^{n} \theta_{i} \Delta \ln Y_{t-1}+\sum_{i=1}^{n} k_{i} \Delta \ln W_{t-1}+\sum_{i=1}^{n} m_{i} \Delta \ln \pi_{t-1}+\varphi_{1} E C T_{t-1}+\varepsilon_{1 t} \\
& \Delta \ln W_{t}=v+\sum_{i=1}^{n} k_{i} \Delta \ln W_{t-1}+\sum_{i=1}^{n} \partial_{i} \Delta \ln Y_{t-1}+\sum_{i=1}^{n} \mu_{i} \Delta \ln \pi_{t-1}+\varphi_{2} E C T_{t-1}+\varepsilon_{2 t} \\
& \Delta \ln \pi_{t}=v+\sum_{i=1}^{n} m_{i} \Delta \ln \pi_{t-1}+\sum_{i=1}^{n} \alpha_{i} \Delta \ln W_{t-1}+\sum_{i=1}^{n} \varpi_{i} \Delta \ln Y_{t-1}+\varphi_{3} E C T_{t-1}+\varepsilon_{3 t}
\end{aligned}
$$

In addition to the variables defined above, the lagged error correction term derived from the long run cointegrating relationship is represented by $E C T_{t-1}$. The serially independent random errors are $\varepsilon_{1 t}, \varepsilon_{2 t}$ and $\varepsilon_{3 t}$ and have means equal to zero and finite covariance matrices. The causality results are obtained by regressing the respective dependent variables against their past values and the past values of other variables. One way of selecting the optimal lag length, $n$, is by using the SBC, where rejection of the null hypothesis is based on the $X^{2}$ statistics from the causality results.

\section{Empirical Results}

\section{Unit root tests}

Our first aim is to investigate the unit root properties of the data series. Below we apply the Augmented Dickey Fuller (ADF) and Phillips Perron (PP) tests to obtain the integrated properties of the data series and to test the null hypothesis of nonstationarity; these results are reported in Table 1. The ADF tests have been applied for both levels and their first differences with an intercept and trend. The ADF and PP statistics for the level variables (inflation, real wages and productivity) do not exceed the critical values in absolute terms. However, when we take the first difference of each of the variables, the ADF and PP statistics are higher than the respective critical values in absolute terms, and therefore the level variables are $I(1)$ and their first differences are stationary.

\{Insert Table 1 about here

\section{Cointegration}

Empirical investigations of the long run effects of inflation and real wages on productivity, including GH test results for a structural break, are reported in Table 2. The four models are estimated over the entire data set and a break date is selected where the absolute value of the ADF test statistic is at its maximum. ${ }^{4}$ The null hypothesis of no cointegration is rejected by the first model (level shift) where the endogenously determined break date occurs for 1985 . Accordingly we select model 1 and infer that there is a long run relationship between inflation, real wages and productivity. ${ }^{5}$ The identification of a structural break in the year 1985 corresponds with a period of great turbulence in the Australian economy, as outlined in

4 See Gregory and Hansen (1996a) for the tabulated critical values of cointegration tests with unknown breaks using the Engle and Granger method.

5 Due to short sample biases, we ignored the sub-sample estimations. However, in any other situation where quarterly or monthly data is used, it would be prudent to estimate cointegrating equations using sub-sample periods considering the break dates from the structural break tests. 
the introduction. Although this structural break is not unsurprising the exact cause of this structural break lies outside of the remit of this paper.

\{Insert Table 2 about here $\}$

Tests were also undertaken to identify the presence of cointegration with the VECM technique. The optimum lag lengths of the VARs are tested with a $4^{\text {th }}$ order model, with the AIC and SBC criteria used to select the lag length of the VAR; both indicate a lag length of 2 periods with AIC and SBC reaching maximums of 289.209 and 282.210 for the second order respectively. To test for cointegration we used the unrestricted intercept and no trend option where the maximal eigenvalue and trace test statistics for the null that there is no cointegration are 21.787 and 38.246 respectively, which are greater than the $95 \%$ critical values 21.120 and 31.540 respectively. For the null that there is one cointegrating vector the corresponding computed values (critical values in the parentheses) are 11.859 (14.880) and 16.459 (17.860) respectively. Therefore, the null hypothesis that there is no cointegration is rejected but the null that the number of cointegrating vectors is one is not rejected. Thus, the cointegration results from the GH test corroborate with those from the VECM.

\section{Long run elasticities}

In this section we present the long run elasticities of the impact of inflation and real wages on productivity. The GH model with level shift (model 1) is estimated with the EG technique and the implied VECM cointegrating vector is normalized on productivity. For comparison, and to identify robustness of our results, we also used GETS, EG, FMOLS and ARDL; these results are reported in Table 3.

\{Insert Table 3 about here $\}$

Table 3 reveals fairly robust results across the six techniques. In all cases real wages are found to have a positive impact on productivity; this result is statistically significant at the 95\% level of statistical significance according to all six estimators. The real wage elasticity estimates range between 0.5 and 0.8 , implying that a 1 percent increase in manufacturing real wages leads to an increase in Australia manufacturing productivity of between 0.5 and 0.8 percent. These empirical results support the hypothesis that a positive relationship exists between real wages and productivity. ${ }^{6}$

Estimates of the effect of inflation on productivity, also presented in Table 3, are negative although their statistical significance is not confirmed across the six estimators. As emphasised in section 2, there are a number of studies which indicate that the relationship is negative, but there are others which suggest that the relationship is spurious. Our results imply that inflation may have a relatively weak negative effect on productivity in Australia. ${ }^{7}$

6 Further investigation is necessary to identify whether this is due to i) higher real wages increasing the opportunity cost of job loss that can stimulate greater work effort to avoid redundancy, ii) higher real wages putting upward pressure on labour costs and causing firms to substitute labour for capital, thereby increasing in the marginal productivity of labour, iii) greater capital stocks increasing the demand for (typically high skilled) labour, thereby increasing the real wage, and stimulating productivity or iv) domestic pressures on real wages stimulating a movement towards the adoption of capital.

7 It could also be because it should be inflation expectations rather than actual inflation which drive investment decisions and therefore future productivity. 


\section{Granger causality}

Since there is a cointegrating relationship between inflation, real wages and productivity, we proceed further to examine both the short run and long run Granger causality within the VECM. The short run causal effects can be obtained by the Wald chi-square tests of the lagged exogenous variables, while the long run causal effects are determined by the significance of the coefficient of the lagged error correction term in equations 3-5. These results are reported in Table 4.

\section{\{Insert Table 4 about here}

In the short run, both real wages and productivity are statistically insignificant at the 95\% level of statistical significance in the inflation equation. However, real wages are statistically significant in the productivity equation and productivity is statistically significant in the real wages equation, also at the $95 \%$ level. This implies that there is a bi-directional causality between real wages and productivity in the short run.

The long run results suggest that the coefficient of the lagged error term $\left(E C M_{t-1}\right)$ is statistically significant at the $95 \%$ level and it has the expected negative sign in the productivity equation. This implies that in the long run both real wages and inflation Granger cause productivity. In other words, the causality runs interactively through the error correction term from real wages and inflation to productivity.

These results have two important implications. First there is some support for the argument that inflation targeting may have a small, positive impact on productivity growth. Second, Australia could successfully adopt policies that focus on raising productivity growth through raising real wages. Of course, productivity growth could also be attained from other avenues including further financial sector reforms and deregulations that were popular in Australia in the 1980s and may be behind the structural break identified here for 1985 . Further investigation could identify whether these results are stable i) if output were measured in terms of total factor productivity, ii) to the inclusion of further variables such as capital stock, relative prices and socio-political factors and iii) at a disaggregated sector level.

\section{Conclusion}

This paper presented an empirical investigation into the effect of inflation and real wages on productivity for Australia using time series annual data for the period 1965 to 2007 and made a contribution to the literature by including tests for structural change. Application of the Gregory and Hansen's (1996a, 1996b) technique to test for structural breaks in the cointegrating relationship indicated the presence of a structural break in 1985 in the form of a level shift with cointegration existing between the variables at $95 \%$ level of statistical significance. Subsequent estimation of the Vector Error Correction Method, General to Specific, Engle and Granger, Fully Modified Ordinary Least Squares and Autoregressive Distributed Lag techniques provided fairly consistent results on the impact of real wages on productivity with an estimated wage elasticity ranging between 0.5 and 0.8 . This implies that a 1 percent increase in real wages leads to an increase in productivity between 0.5 and 0.8 percent. Similar empirical estimates of the inflation coefficient were negative and weakly statistically significant across the six estimators, implying that inflation may have only a weak and negative effect on productivity in Australia. Application of Granger causality tests revealed a bi-directional causality running between real wages and productivity. The results suggest that real wages and inflation Granger cause productivity in the long run. 


\section{References}

Alexander, C. O. (1993) The changing relationship between productivity, wages and unemployment in the UK, Oxford Bulletin of Economics and Statistics 55, 87-102.

Bardsen, G., Hurn, S. and Mchugh, Z. (2007) 'Modelling wages and prices in Australia', The Economic Record, 83, $143-58$

Bildirici, M. and Alp, E. A. (2008) The relationship between wages and productivity: Tar unit root and Tar cointegration approach, International Journal of Applied Econometrics and Quantitative Studies, 5, 93 110

Bitros, C. C. and Panas, E. E. (2001) Is there an inflation productivity trade-off? Some evidence from the manufacturing sector in Greece, Applied Economics, 33, 1961-9

Blanchard, O. J. (1985) The wage price spiral, National Bureau of Economic Research Working Paper: 1771.

Blanchard, O. J. and Katz, L. (1999) Wage dynamics: Reconciling theory and evidence, American Economic Review, 89, 69-74.

Buck, A. J. and Fitzroy, F. (1988) 'Inflation and productivity growth in the federal republic of Germany, Journal of Post Keynesian Economics, 10, 428-44

Cameron, N., Hum, D. and Simpson, W. (1996) Stylized facts and stylized illusions: Inflation and productivity revisited, Canadian Journal of Economics, 29, 152-62.

Christopolous, D. K. and Tsionas, E. G. (2005) Productivity growth and inflation in Europe: Evidence from panel cointegration tests, Empirical Economics, 30, 137-50.

Clark K. P. (1982) Inflation and the productivity decline, American Economic Review, Papers and Proceedings, 72, 149-54.

Crafts. N. (1992) Productivity growth reconsidered, Economic Policy, 10, 387-426.

De Gregorio, J. (1992) The effects of inflation on economic growth: Lessons from Latin America, European Economic Review, 36, 417-25.

Denny, M. and May, D. (1977) The existence of a real value added function in the Canadian manufacturing sector, Journal of Econometrics, 5, 55-69.

Dritsakis, N. (2004) A causal relationship between inflation and productivity: An empirical approach for Romania, American Journal of Applied Sciences, 1, 121-8.

Engle, R. F. and Granger, C. W. J. (1987) Cointegration and error correction representation, estimation and testing, Econometrica, 55, 251-76.

Erenburg, S. J. (1998) Productivity, private and public capital and real wage in the US, Applied Economics Letters, 5, 491-5

Feijo, C. (1997) Growth and inflation in the Brazilian industrial sector in the 1970s: A post Keynesian model, Journal of Post Keynesian Economics, 19, 437-60.

Fountas, S., Lally, B. and Lin, J. (1999) The relationship between inflation and wage growth in the Irish economy, Applied Economics Letters, 6, 317-21.

Freeman, D. G. and Yerger, D. B. (2000) Does inflation lower productivity? Time series evidence on the impact of inflation on labour productivity in 12 OECD nations, Atlanta Economic Journal, 28, 315-32.

Freeman, D. G. and Yerger, D. B. (1998) Inflation and multifactor productivity growth in Germany: A response to Smyth, Applied Economics Letters, 5, 271-4

Ghali, K. H. (1999) Wage growth and the inflation process: A multivariate cointegration analysis, Journal of Money, Credit and Banking, 31, 417-31.

Gordon, R. J. (1988) The role of wages in the inflation process, American Economic Review, 78, $276-83$.

Gordon, R. J. (1987) Productivity, wages, and prices inside and outside of manufacturing in the US, Japan and Europe, European Economic Review, 31, 685-739

Gordon, R. J. (1984) The role of wages in the inflation process, American Economic Review, 78, $276-83$.

Gregory, A. W. and Hansen, B. E. (1996a) Residual-based tests for cointegration in models with regime shifts, Journal of Econometrics, 70, 99-126.

Gregory, A. W. and Hansen, B. E. (1996b) Tests for cointegration in models with regime and trend shifts, Oxford Bulletin of Economics and Statistics, 58, 555-559.

Geary, P. (1976) World prices and the inflationary process in a small open economy: The case of Ireland, The Economic and Social Review, 7, 391-400.

Gunay, A., Metin-Ozcan, K. and Yeldan, E. (2005) Real wages, profit margins and inflation in Turkish manufacturing under post liberalization, Applied Economics, 37, 1899-905

Hall S. G. (1986) An application of the Granger and Engle two-step estimation procedure to United Kingdom aggregate wage data, Oxford Bulletin of Economics and Statistics, 48, 229- 239.

Hendry, D. F. (2001) Modelling UK inflation, 1987-1991, Journal of Applied Econometrics, 16, 255-75 
Hondroyiannis, G. and Papapetrou, E. (1998) Temporal causality and the inflation-productivity relationship: Evidence from eight low inflation OECD countries, International Review of Economics and Finance, 7, 117-35

Hondroyiannis, G. and Papapetrou, E. (1997) Seasonality cointegration and the inflation, productivity and wage growth relationship in Greece, Social Science Journal, 34, 235-47.

Hsiao, C. (1982) Autoregressive modeling and causal ordering of economic variables, Journal of Economic Dynamics and Control, 4, 243-59

Hsiao, C. (1981) Autoregressive modeling and money-income causality detection, Journal of Monetary Economics, 7, 85-106

Hsu, P. F. (2005) Inter-industry wage premiums and industry-specific productivity in Taiwan, Applied Economics, 37, 1523-33

International Financial Statistics, December, 2008. IMF CD-ROM (Washington DC: International Monetary Fund).

Jarrett, J. P. and Selody, J. G. (1982) The productivity inflation nexus in Canada 1963-1979, Review of Economics and Statistics, 64, 361-7.

Johansen, S. (1991) Estimation and hypothesis testing of cointegration vectors in Gaussian vector autoregressive models, Econometrica, 59, 1551 -80.

Johansen, S. (1988) Statistical analysis of cointegration vectors, Journal of Economic Dynamics and Control, 12, 231-54

Johansen, S. and Juselius, K. (1990) Maximum likelihood estimation and inference on cointegration with applications to the demand for money, Oxford Bulletin of Economics and Statistics, 52, 169-210

Kumar, S. (2009) Structural breaks and exports in Philippines, Global Economy Journal, 9, 1-8

L'horty, Y. and Rault, C. (2004) Inflation, minimum wage and other wages: an econometric study of French macroeconomic data, Applied Economics, 36, 277-90.

Mahadevan, R. and Asafu-Adjaye, J. (2006) Is there a case for low inflation-induced productivity growth in selected Asian economies?, Contemporary Economic Policy, 24, 249-61.

Mahadevan, R. and Asafu-Adjaye, J. (2005) The productivity-inflation nexus: The case of the Australian mining sector, Energy Economics, 27, 209-24.

McKissack, A., Chang, J., Ewing, C. and Rahman, J. (2008) Structural effects of a sustained rise in the terms of trade, Australian Treasury

Mehra, Y. P. (2000) Wage-price dynamics: Are they consistent with cost-push?, Federal Reserve Bank of Richmond Economic Quarterly, 86, 27-43.

Mehra, Y. P. (1993) Unit labor costs and the price level, Federal Reserve Bank of Richmond Economic Quarterly, 79, 35-51

Mehra, Y. P. (1991) Wage growth and the inflation process: An empirical note, American Economic Review, 81, 931-7

Metin-Ozcan K., Voyvoda, E. and Yeldan E. (2002) 'The impact of the liberalization program on the price-cost margin and investment of Turkey's manufacturing sector after 1980, Emerging Markets Finance and Trade, 38, 71-101.

Mora, T., Lopez-Tamayo, J. and Surinach, J. (2005) Are wages and productivity converging simultaneously in euro-area countries?, Applied Economics, 37, 2001-8.

Palokangas, T. (1997) Inflation and growth in an open economy, Economica, 64, 125-41

Narayan, P. K. and Smyth, R. (2009) The effect of inflation and real wages on productivity: new evidence from a panel of G7 countries, Applied Economics, 41, 1285-1291.

Rao, B. B and Kumar, S. (2009) Cointegration, structural breaks and demand for money in Bangladesh, forthcoming in Applied Economics, 41(10), 1277-83

Rao, B. B and Kumar, S. (2007) Structural breaks, demand for money and monetary policy in Fiji, Pacific Economic Bulletin, 22, 54-62.

Sbordone, A. and Kuttner, K. (1994) Does inflation reduce productivity?, Economic Perspectives, 18, 2-14

Smyth, D. J. (1995) Inflation and total factor productivity in Germany, Weltwirtschaftliches Archiv, 131, 413-5.

Strauss, J. and Wohar, M. (2004) The linkage between prices, wages and labour productivity: A panel study of manufacturing industries, Southern Economic Journal, 70, 920-41.

Tsionas, E. G. (2003a) Inflation and productivity in Europe: an empirical investigation, Empirica, 30, 39-62.

Tsionas, E. G. (2003b) Inflation and productivity: empirical evidence from Europe, Review of International Economics, 11, 114-29.

Wakeford, J. (2004) The productivity-wage relationship in South Africa: An empirical investigation, Development South Africa, 21, 109-32.

Zellner, A. (1962) An efficient method of estimating seemingly unrelated regressions and tests for aggregation bias, Journal of the American Statistical Association, 57, 348-68 
Table 1: Results of ADF and PP Unit Root Tests

\begin{tabular}{|l|c|c|c|c|c|c|}
\hline Variables & $\ln \mathrm{Y}$ & $\Delta \ln \mathrm{Y}$ & $\ln \mathrm{W}$ & $\Delta \ln \mathrm{W}$ & $\ln \pi$ & $\Delta \ln \pi$ \\
\hline \multirow{2}{*}{ ADF Statistic } & 1.375 & 3.887 & 2.008 & 6.832 & 1.356 & 3.992 \\
& {$[1]$} & {$[0]$} & {$[0]$} & {$[1]$} & {$[0]$} & {$[1]$} \\
\hline \multirow{2}{*}{ PP Statistic } & 2.976 & 4.904 & 0.854 & 7.112 & 2.065 & 5.355 \\
& {$[3]$} & {$[1]$} & {$[2]$} & {$[2]$} & {$[4]$} & {$[3]$} \\
\hline
\end{tabular}

Notes: The ADF and PP critical values at 5\%, respectively, are 3.521 and 3.519. The lag lengths for ADF and $\mathrm{PP}$ are in parenthesis. 
Table 2: Cointegration Tests with Structural Breaks 1965-2007

\begin{tabular}{|c|c|c|c|c|}
\hline Model & $\begin{array}{c}\text { Break } \\
\text { Date }\end{array}$ & $\begin{array}{c}\text { GH Test } \\
\text { Statistic }\end{array}$ & $\begin{array}{c}5 \% \text { Critical } \\
\text { Value }\end{array}$ & $\begin{array}{c}\text { Evidence of } \\
\text { Cointegration }\end{array}$ \\
\hline$(1)$ & 1985 & -5.632 & -3.603 & YES \\
\hline$(2)$ & 1985 & -2.951 & -3.603 & No \\
\hline$(3)$ & 1994 & -2.005 & -3.190 & No \\
\hline$(4)$ & 1987 & -1.688 & -3.190 & No \\
\hline
\end{tabular}

Model (1) is the level shift. Model (2) is level shift with trend. Model (3) is regime shift where intercept and slope coefficients change. Model (4) is regime shift where intercept, trend and slope coefficients change. 
Table 3. Alternative Long run Estimates

\begin{tabular}{|l|c|c|c|c|c|c|}
\hline & GETS & EG & ARDL & FMOLS & VECM & GH \\
\hline \multirow{2}{*}{ Constant } & 3.728 & 4.292 & 4.763 & 4.547 & - & 1.067 \\
& $(3.53)^{*}$ & $(6.88)^{*}$ & $(5.33)^{*}$ & $(7.88)^{*}$ & & $(2.06)^{*}$ \\
\hline \multirow{2}{*}{$\ln \mathrm{W}$} & 0.502 & 0.573 & 0.795 & 0.635 & 0.554 & 0.608 \\
& $(2.05)^{*}$ & $(3.41)^{*}$ & $(3.44)^{*}$ & $(4.09)^{*}$ & $(2.11)^{*}$ & $(2.95)^{*}$ \\
\hline \multirow{2}{*}{$\ln \pi$} & -0.751 & -0.793 & -0.604 & -0.788 & -0.771 & -0.586 \\
& $(1.80)^{*}$ & $(1.87)^{*}$ & $(1.80)^{*}$ & $(1.09)$ & $(1.12)$ & $(1.37)$ \\
\hline
\end{tabular}

In all cases, the dependent variable is productivity. The absolute $t$-ratios are reported underneath the coefficients in parenthesis. Significance at $5 \%$ is represented by *. (-) indicates estimate not available. 
Table 4. Results of Granger Causality Test

\begin{tabular}{|l|c|c|c|c|}
\hline $\begin{array}{l}\text { Dependent } \\
\text { Variable }\end{array}$ & $\Delta \ln Y_{t}$ & $\Delta \ln W_{t}$ & $\Delta \ln \pi_{t}$ & $E C M_{t-1}$ \\
\hline$\Delta \ln Y_{t}$ & - & $\begin{array}{c}0.234 \\
(2.16)^{*}\end{array}$ & $\begin{array}{c}-0.138 \\
(0.21)\end{array}$ & $\begin{array}{c}-0.372 \\
(2.66)^{*}\end{array}$ \\
\hline$\Delta \ln W_{t}$ & $\begin{array}{c}0.039 \\
(3.52)^{*}\end{array}$ & - & -0.749 & - \\
& 0.015 & 0.162 & - & - \\
\hline$\Delta \ln \pi_{t}$ & $(0.21)$ & $(1.54)$ & - & - \\
\hline
\end{tabular}

The $t$-ratios are given in parenthesis. The significance at 5\% level is denoted by *. 